DOI https://doi.org/10.30525/978-9934-588-37-2.1.14

\title{
ПРОБЛЕМА ПРОФЕСІЙНОЇ ПІДГОТОВКИ МАЙБУТНІХ ФАХІВЦІВ ІЗ ГРОМАДСЬКОГО ЗДОРОВ'Я: ЗАРУБІЖНИЙ ДОСВІД ТА ВІТЧИЗНЯНІ ПЕРСПЕКТИВИ
}

\author{
Дяченко М. Д., Закусилова Т. О.
}

\section{ВСТУП}

Здоров'я нації - необхідна умова процвітання держави та іiі соціально-економічного розвитку, одна 3 найбільших цінностей країни. Основним призначенням української системи охорони здоров'я десятиліттями було надання медичної допомоги людям із певними захворюваннями, проте завдання збереження, зміцнення того здоров'я, що має людина, та профілактики його порушення й виникнення хвороби не стало пріоритетним. Наразі одним із першочергових завдань галузі охорони здоров'я $\epsilon$ забезпечення кваліфікованим кадровим потенціалом 3 високим рівнем компетентності згідно 3 міжнародними стандартами. Основою профілактичної медицини повинна стати чітко структурована злагоджена система громадського здоров'я.

У сучасних умовах ринкової економіки, з урахуванням факторів людської діяльності й навколишнього середовища, що негативно впливають на здоров'я людини, в контексті модернізації галузі медицини в Україні зростають вимоги до якості підготовки майбутніх медичних працівників, від професіоналізму яких безпосередньо залежить майбутнє здорової нації. Це зумовлює необхідність пошуку нових шляхів та напрямів професійної підготовки майбутніх фахівців зі спеціальності «Громадське здоров'я», що може стати запорукою забезпечення ефективності виконання ними своїх професійних функцій і завдань, спрямованих на збереження здорового генофонду нації.

Головною метою освіти України визнано створення умов для особистісного розвитку молодого покоління, здатного навчатися впродовж життя, створювати й розвивати цінності громадянського суспільства, сприяти консолідації української нації, інтеграції України в європейський і світовий простір як конкурентоспроможної та процвітаючої держави. 


\section{1. Шляхи та напрями професійної підготовки майбутніх фахівців із громадського здоров'я: педагогічний аспект}

Як зазначено в «Основах законодавства України про охорону здоров'я» ${ }^{1}$, професійна підготовки майбутніх лікарів має бути орієнтована на формування не лише лікарської компетентності, а й готовності випускників медичних ЗВО до участі в забезпеченні гармонійного розвитку фізичних $\mathrm{i}$ духовних сил, високої працездатності та довголітнього активного життя громадян, усунення факторів шкідливого впливу на їхнє здоров'я.

У науковому світі розрізняють здоров'я індивідуальне та суспільне (громадське), на рівні індивідуального здоров'я людини це - фізична витривалість, емоційна стійкість, працездатність, адаптивність, креативність, моральність, цілеспрямованість ${ }^{2}$. 3 позиції громадського - здоров'я потребує збереження його i примноження. Як підкреслює В. Грибан, «людина розумна повинна розглядати своє здоров'я не лише як особистий капітал, але і як державну цінність» ${ }^{3}$.

Проблема збереження та зміцнення здоров'я населення за всіх часі була однією 3 ключових у суспільстві. Здоров'я нації - це показник цивілізованості держави, що відображає рівень іiі соціальноекономічного розвитку, головний критерій доцільності й ефективності всіх сфер діяльності людини. Наразі в Україні тенденція погіршення здоров'я населення набула загрозливого рівня. Це зумовлено збідненням значної частини населення, погіршенням екологічної ситуації, розповсюдженням здоров'яруйнівних стереотипів поведінки, зниженням доступності до якісних медичних послуг, здоров'явитратністю сучасної системи освіти ${ }^{4}$.

Здоров'я - це стан повного фізичного, душевного та соціального благополуччя, а не лише відсутність хвороб або фізичних вад 5 .

Майбутнім фахівцям із громадського здоров'я необхідно усвідомити, що здоров'я - це не тільки відсутність хвороб, але й найменша вірогідність їхнього розвитку в конкретних умовах

1 Закон України «Основи законодавства України про охорону здоров’я». URL: http://bs-staff.com.ua/pb_ot/1085_165_37.html.

${ }_{2}$ Гончаренко М.С. Духовность, здоровье, образование : учеб. пособ. Харьков : «БУРУН КНИГА», Киев : КНТ, 2011. 176 с., с. 85.

3 Грибан В.Г. Валеологія : навч. посібник для студентів ВНЗ. Київ : Центр навчальної літератури, 2008. 256 с., с. 11.

4 Загальна теорія здоров'я та здоров'язбереження : колективна монографія / за заг. ред. проф. Ю.Д. Бойчука. Харків : Вид. Рожко С.Г., 2017. 488 с.

Устав Всемирной Организации Здравоохранения. URL: http://apps.who.int/ $\mathrm{gb} / \mathrm{bd} / \mathrm{PDF} / \mathrm{bd} 47 / \mathrm{RU} /$ constitution.ru.pdf. 
життєдіяльності людини, що можлива при добрій адаптації (пристосованості) до певних чинників довкілля ${ }^{6}$.

У цьому контексті актуальним $є$ вивчення зарубіжного досвіду підготовки майбутніх фахівців зі спеціальності «Громадське здоров’я» в закладах вищої медичної освіти. Так, наприклад, у вищих медичних навчальних закладах Казахстану тривалість підготовки фахівців зі спеціальності «Громадське здоров’я» (кваліфікаційний рівень «бакалавр») - 5 років. Цикл загальноосвітніх дисциплін бакалаврату (ЗОД) складається 3 дисциплін обов'язкового компонента й може включати компоненти за вибором. Цикли базових дисциплін (БД) i профілюючих дисциплін (ПД) включають дисципліни обов'язкового компонента і компонента за вибором ${ }^{7}$. Зміст циклу ЗОД становить 25\% від загального обсягу дисциплін типового навчального плану або 33 кредити і включає такі дисципліни: історія Казахстану, філософія, казахська (російська) мова, іноземна мова, інформатика, екологія та сталий розвиток, політологія, соціологія, основи економічної теорії, основи права, основи безпеки життєдіяльності та фізична культура. При цьому фізична культура реалізується в межах додаткових видів навчання та не включається до загального обсягу кредитів циклу ЗОД. Рекомендується включати до навчальних планів такі дисципліни: культурологія, психологія, самопізнання, інноваційний менеджмент. Обсяг дисциплін циклу БД становить 50\% від загального обсягу дисциплін типового навчального плану або 64 кредити, 3 них 20 кредитів відводиться на дисципліни обов'язкового компонента i 44 кредити - на дисципліни за вибором. Підготовка в магістратурі зі спеціальності «Громадське здоров'я» розподіляється за двома напрямами: профільним та науково-педагогічним, від цього залежить тривалість навчання, дисципліни, які вивчаються та види професійної діяльності випускників магістратури. Терміни освоєння освітньої програми магістратури: при профільній підготовці становить від 1 до 1,5 року; при науковій та педагогічній підготовці - 2 роки.

На думку К. Вишньовської, «реформа охорони здоров’я, яку проводить та чи інша цивілізована країна, передбачає насамперед поліпшення стану здоров'я членів суспільства, підвищення ефективності системи охорони здоров'я та більшу доступність людей до медичних послуг» ${ }^{8}$. Дослідниця вважає, що однією з причин різкого

6 Апанасенко Г.Л. Попова Л.А. Медицинская валеология. Ростов-на-Дону : Феникс, 2000. 243 с., с. 15.

7 Грузєва Т.С., Курило Т.М. Особливості підготовки фахівців громадського здоров’я в Республіці Казахстан. Україна. Здоров'я нації. 2017. № 1 (42). С. 162-165.

${ }^{8}$ Вишньовська К. Проблеми реформування системи охорони здоров'я в Україні. Світ фінансів. 2008. № 3 (16). С. 78-86. 
зростання витрат фахівці вважають розвиток нових, надзвичайно дорогих технологій, новітніх методик лікування й діагностики хворих Якщо, наприклад, польська система охорони здоров'я працює зараз достатньо успішно, то на вітчизняну впливають негативні тенденції.

У процесі реалізації реформ систем охорони здоров'я за різними елементами систем у цих державах, попри певні особливості, більшість реформ у сфері охорони здоров'я в Центральній та Східній Європі відбувалися через реалізацію схожих ініціатив у національних системах охорони здоров'я.

Здоров'я $є$ природним правом людини, в якому поєднується (вирішується) протиріччя між свободою людини (можливість контролювати своє здоров'я та забороняти втручання в тіло без іiі згоди) та залежністю від інших суб'єктів на основі рівності з ними. Кожна країна на основі історичного досвіду, ментальних принципів, фінансових можливостей різними засобами вирішує це протиріччя. Реалізація суб'єктивного права людини на здоров'я найкращим чином реалізується в межах об'єктивного права, саме тому необхідна правова структура, що регламентує права тих людей (пацієнтів), які звертаються за медичною допомогою з метою охорони свого здоров'я'

Аналіз медичної та педагогічної літератури свідчить про те, що вчені загалом виокремлюють шість основних типів сутнісних елементів визначення здоров'я: 1) здоров'я як норма функціонування організму на всіх рівнях його організації; 2) здоров'я як динамічна рівновага (гармонія) життєвих функцій організму; 3) здоров'я як повноцінне виконання основних соціальних функцій, участь у житті суспільства й активна трудова діяльність; 4) здатність організму адаптуватися до умов навколишнього середовища, що змінюється; 5) відсутність патологічних змін і нормальне самопочуття; 6) повне фізичне, духовне, розумове й соціальне благополуччя.

Основним завданням майбутніх фахівців із громадського здоров'я $\epsilon$ розробка дієвих, ефективних заходів, спрямованих на збереження здоров'я населення. Відтак - у процесі професійної вищої медичної освіти студенти спеціальності «Громадське здоров'я» повинні:

1) оволодіти професійними знаннями: 3 основ політики в охороні здоров'я та соціальної політики, економіки охорони здоров'я, теорії управління, особливостей та закономірностей формування здоров'я населення, методів його моніторингу, аналізу та оцінки його стану; засвоїти принципи та функції системи громадської охорони здоров'я;

2) усвідомити чинники впливу на цей процес;

9 Загальна теорія здоров'я та здоров'язбереження : колективна монографія / за заг. ред. проф. Ю.Д. Бойчука. Харків : Вид. Рожко С. Г., 2017. 488 с. 
3) здобути навички адміністративно-управлінської, аналітичної, експертно-консультативної, санітарно-просвітницької, протиепідемічної, комунікативної діяльності;

4) сформувати компетенції щодо правових, економічних, етичних, валеологічних засад медичної професії; невідкладних терапевтичних інтервенцій; безпечності харчових продуктів та захисту споживачів;

5) розвинути вміння: критичного аналізу нових медичних знань, організації профілактики захворювань населення, пропаганди здорового способу життя, застосування технологій управління у сфері громадського здоров’я тощо.

У процесі професійної підготовки майбутніх фахівців із громадського здоров'я ефективним $€$ застосування моделювання квазіпрофесійної діяльності в умовах організаційно-комунікативних ігор (розігрування професійних ситуацій за ролями, студенти виступають керівниками, заступниками та працівниками структурних підрозділів органів управління охороною здоров'я державних адміністрацій та органів місцевого самоврядування, закладів охорони здоров'я, працівниками Центру громадського здоров'я, Державної служби України з питань безпечності харчових продуктів та захисту споживачів, Державної служби України з питань праці тощо.)

Можуть використовуватися такі види комунікативних ігор: за характером методичного процесу (навчальні, тренінгові, узагальнюючі, контролюючі); за ігровою методикою (предметні, сюжетні, рольові, ділові, імітаційні); за специфікою ігрової участі (колективні, групові, міжособистісні); за технікою процедури (ігри-тренінги, гра-самоаналіз, гра-рефлексія) тощо. У процесі професійної підготовки майбутніх фахівців із громадського здоров'я в таких іграх основним об'єктом виступає активне професійне мовлення, спрямоване на певного адресата («підлеглого», «колегу-медика», «колегу-працівника Центру громадського здоров'я та ін.), який взаємодіяв 3 адресантом у конкретному комунікативному контексті.

Застосування таких організаційно-комунікативних ігор сприяє розвитку інтересу студентів до майбутньої професійної діяльності; їхній соціальній і фаховій взаємодії; формуванню культури діалогічного спілкування; закріпленню мовленнсвих правил і норм усного професійного мовлення управлінській сфері галузі охорони здоров'я; розкриттю індивідуальних особливостей майбутніх фахівців із громадського здоров'я; підготовці до професійного спілкування під час проходження практики та майбутньої фахової діяльності; ініціювання широкої дискусії щодо вирішення питань збереження громадського здоров'я та запобігання інфекційним захворюванням, щодо організації пропаганди здорового способу життя; забезпеченню 
емоційної позитивної атмосфери під час відтворення знань, отриманих у процесі вивчення дисциплін: «Соціальна медицина, громадське здоров'я», «Історія медицини», «Інформатика», «Етика», «Гігієна», «Екологія», «Епідеміологія», «Соціологія та медична соціологія», «Основи економічних теорій» тощо.

Рольові ігри, зокрема імітаційні, допомагають створити модель певної ситуації, поведінки чи дії в навчальному процесі й наблизити навчання до майбутньої професійної діяльності в галузі медицини. Організація індивідуальної ситуації успіху як метод є цілеспрямованим, організованим поєднанням умов, за яких створюється можливість досягти значних результатів у діяльності як окремо взятої особистості, так i колективу в цілому. У процесі створення ситуації успіху відбувається орієнтація на індивідуально-творчий розвиток особистості, що передбачало вибір завдань і способів діяльності залежно від здібностей та можливостей студента. Це сприяє забезпеченню якісно нового рівня професійної підготовки, стимулює розвиток індивідуальних здібностей і творчого потенціалу. Особливо ефективним $\epsilon$ використання інноваційних технологій, зокрема технології індивідуально-творчого навчання.

Творчий залік у контексті вивчення дисциплін гуманітарного циклу став однією 3 орієнтованих на компетенцію форм перевірки якості знань майбутніх фахівців із громадського здоров'я, що є не просто підсумковою роботою, а діяльністю, націленою на активізацію внутрішньої мотивації студента до навчання. Творчий залік використовується як один із видів контролю, що стимулює розширення медичного кругозору. При цьому творчий залік проводився в індивідуальній та груповій формах.

Презентація також $\epsilon$ однією 3 ефективних форм проведення практичних занять; використання презентації стає особливо доцільним при розгляді великої, складної теми. Грунтовно вивчаючи матеріал за одним із питань теми, студенти-медики таким чином практикуються колективно працювати у професійній групі, де потрібно не лише слухати, але й почути інших, вміти обгрунтувати свою думку, висловити власне бачення проблеми та шляхи ії вирішення, виявляти здатність до генерування ідей, до прогнозування можливих результатів. Робота проводиться в підгрупах, які формуються за допомогою викладача і є рівносильними за складом. Форму презентації учасники обирають самостійно, роботу намагаються організувати так, щоби зміст представленого матеріалу повністю розкривав запропоновану для розгляду проблему. Під час такого заняття формуються групи по 5-6 чоловік, що забезпечує підготовку результативної презентації. В той час, як одна підгрупа знайомить присутніх із результатами своєї 
роботи, дві інші - уважно стежать за процесом представлення, ставлять запитання, аналізують дії своїх колег-однокурсників. Учасники групи, яка демонструвала презентацію, відповідають на запитання.

Одним із ефективних методів $є$ портфоліо, що в процесі професійної підготовки в межах реалізації компетентнісного підходу використовується для оцінювання й самооцінювання навчальних досягнень суб'єктів освітнього простору, що в деяких країнах (США, Великобританії, Німеччині тощо) й розуміється як складник так званого «автентичного оцінювання» в межах особистісно орієнтованого підходу до навчання 3 метою 3'ясування рівня сформованості в особистості певних якостей в умовах, максимально наближених до професійної діяльності. Основною метою формування навчального портфоліо майбутніх фахівців із громадського здоров'я $є$ накопичення інформації про індивідуальні досягнення студента в процесі вивчення дисципліни. Цей вид діяльності сприяє розвитку вмінь майбутніх фахівців із громадського здоров'я планувати свій розвиток, аналізувати зібрану інформацію. Портфоліо - це своєрідний звіт про те, що студент дізнався у процесі вивчення певної дисципліни, як він думає, аналізує, синтезує. Робота над портфоліо сприяє формуванню таких умінь, як планування розвитку своєї діяльності, систематизування, порівнювання, цілепокладання, конкретизування професійних завдань, прогнозування, проектування; розвиває організаційні, комунікативні, рефлексивні вміння, відповідальність, ініціативність, самостійність, здатність до самоосвіти й перманентного професійного й особистісного саморозвитку в процесі майбутньої фахової діяльності.

Дієвим заходом $\epsilon$ коучинг, який у Запорізькому державному медичному університеті, наприклад, проводиться на базі лікувальних установ (КЗ «Запорізька міська багатопрофільна дитяча лікарня № 5», публічне акціонерне товариство «Мотор Січ», Запорізька обласна клінічна лікарня 30, відділкова клінічна лікарня Придніпровської залізниці, КУ «Запорізький обласний клінічний онкологічний диспансер» Запорізької обласної ради; КУ «Запорізька міська дитяча лікарня № 1» тощо).

Коучинг - це взаємостосунки між викладачем і студентами, коли викладач ефективно організовує процес пошуку студентами кращих відповідей на питання, що їх цікавлять. Коуч допомагає студентам розвиватися, закріплювати нові навички і досягати високих результатів у своїй майбутній професії ${ }^{10}$. Парадигма коучингу як особливого стилю навчальної взаємодії базується на таких препозиціях: люди здатні

10 Романова С.M. Коучинг як нова технологія в професійній освіті. URL: http://ecobio.nau.edu.ua/index.php/VisnikPP/article/viewFile/2145/2136. 
змінюватися лише в тих випадках, коли самі захочуть цього і готові до цього; наші переконання щодо власних можливостей напряму пов'язані 3 нашими досягненнями; те, як ми визначаємо успіх, здійснює прямий вплив на наші досягнення; ми обмежуємо наш потенціал межами наших переконань (наприклад, передбачаючи, що певні речі неможливі через зовнішні або ситуаційні бар'єри); люди вчаться лише тоді, коли дійсно залучені в процес; ми можемо вчитися за допомогою всього, що робимо, проте навчання відбувається лише тоді, коли ми мислимо i будуємо плани на майбутнє; щоб допомагати іншим, ми повинні безперервно прогресувати самі.

Оновлення системи науково-методичної роботи нерозривно пов'язане 3 розвитком нового педагогічного мислення, вивченням інноваційних технологій навчання, що базуються на комп'ютерній підтримці навчальної діяльності та інтенсифікації навчального процесу, підвищує ефективність навчально-виховного процесу та професійний рівень педагогів ${ }^{11}$.

Таким чином, головною метою системи охорони здоров'я України $\epsilon$ збереження здоров'я нації, запобігання захворюванням i надання кваліфікованої медичної допомоги 3 використанням найновіших здоров'язбережувальних технологій.

\section{2. Формування у майбутніх фахівців із громадського здоров'я} готовності до здоров'язбережувальної діяльності: медичний аспект

Як уже зазначалося, основним завданням майбутніх фахівців із громадського здоров'я $\epsilon$ розробка дієвих, ефективних заходів, спрямованих на збереження здоров'я населення. Поняття «здоров'я» $\epsilon$ наскрізною категорією, бо використовується в багатьох галузях науки, в яких досліджуються проблеми існування та діяльності людини, функціонування ії організму (філософія, біологія, медицина, соціологія, психологія, педагогіка, валеологія тощо). Здоров'я є фундаментальною характеристикою життя людини і внаслідок тривалої історії свого вивчення й дослідження фахівцями різних наукових напрямів має пенні визначення, яких деякі вчені нараховують біля трьохсот ${ }^{12}$.

Як зауважує В. Оржеховська ${ }^{13}$, всі складові частини здоров'я (фізична, соціальна, психічна і духовна) тісно пов'язані між собою: на

11 Павленко Л.А. Впровадження інноваційних освітніх технологій як основа оновлення системи науково-методичної роботи закладу освіти. URL: http://virtkafedra.ucoz.ua/el_gurnal/pages/vyp7/konf2/Pavlenko_LA.pdf.

12 Бойченко Т.Є. Освітні програми формування здорового способу життя молоді. Київ : Укр. ін-т соціальних досліджень, 2005. 120 с. $216 \mathrm{c}$.

${ }_{13}$ Оржеховська В.М. Духовність і здоров'я. Черкаси : ПП Чабаненко Ю.А., 2007. 
базі фізичного здоров'я розвивається соціальне здоров'я, на основі фізичного та соціального формується психічне i, як вершина формується духовне здоров'я людини.

На думку В. Ліщука, здоров'я потрібно трактувати 3 погляду концепції активного самозбереження та саморозвитку організму ${ }^{14}$.

Поняття «культура здоров'я» полягає в тому, що здоровий спосіб життя, як основний його стрижень - це науково обгрунтований, культурний, найбільш раціональний і оптимальний у конкретних умовах, усвідомлений особистістю як життєва необхідність, спосіб життя ${ }^{15}$.

Як зазначають учені Ю. Кіт і І. Піскун, основним критерієм фізичного здоров'я є енергопотенціал біосистеми, оскільки життєздатність будь-якого живого організму залежить від його акумуляції та мобілізації для забезпечення фізіологічних функцій. Частка аеробної енергопродукції $\epsilon$ найбільшою в сумі енергопотенціалу, тобто максимальна величина аеробних можливостей організму є основним критерієм його фізичного здоров'я і життєдіяльності. Максимальне споживання кисню, на думку авторів, $є$ кількісним виразом стану здоров'я людини ${ }^{16}$.

Із позиції клініцистів розрізняють: фізичне здоров'я (функціонування людського організму і стан здоров'я кожної з його систем); розумове здоров'я (здатність відшукувати й отримувати інформацію, вміння правильно іiі використовувати щодо власного організму); психічне здоров'я (стан душевного благополуччя, відсутність хворобливих психічних проявів, адекватна регуляція поведінки та діяльності); емоційне здоров'я (здатність розуміти наші почуття і виражати їх, емоційний комфорт); соціальне здоров'я (відчуття й позиціонування себе в колективі, родині, у взаєминах 3 друзями, коханими і всіма тими, з ким ми спілкуємось; адекватні способи самовираження та власних досягнень); духовне здоров'я (серцевина всіх видів нашого здоров'я).

Виокремлюють також рівень здоров'я (інтенсивність прояву життя в нормальних умовах середовища, яке визначається тренованістю структур клітин) і кількість здоров'я (межі змінених зовнішніх умов, в яких ще продовжується життя).

На думку вчених, майбутні фахівці з громадського здоров'я повинні мати «навички загальної медичної практики, що включають, перш за все, проведення ефективного медичного обстеження, застосування здоров'язбережувальної моделі практичної медицини, тобто

14 Лищук В.Д. Научные основы здоровья. Вестник АМН. 1994. № 4. С. 55-59.

15 Митяева А.М. Здоровьесберегающие педагогические технологии : учеб. пособ. Москва : Изд. центр «Академия», 2008. 192 с., с. 21.

16 Піскун І.П., Кіт Ю.В. Безпека життєдіяльності (психофізіологічні аспекти) : навч. посіб. Львів : «Афіша», 2000. 239 с., с. 41. 
врахування соціальних, культурних, екзистенційних, психологічних чинників патологічних станів людини, аналіз та інтерпретацію даних медичного обстеження задля встановлення діагнозу, визначення i проведення (під наглядом фахівця) терапевтичних заходів згідно зі стандартами надання медичної допомоги тощо; вміння i навики управлінської діяльності, що стосуються передусім ефективного планування своєї професійної діяльності, організації командної діяльності медичного персоналу, належного використання ресурсів системи охорони здоров'я, ведення медичної обліково-звітної документації, проведення моніторингу результативності й ефективності професійної діяльності тощо; наявність соціально-комунікативних якостей, до яких належать комунікативні здібності та досвід міжособистісної взаємодії на засадах партнерства, загальнолюдських соціально-моральних цінностей і етичних норм, повага до особистості пацієнта, його прав, зокрема на конфіденційність, самовизначення, особистісну свободу, врахування його потреб і побажань, спілкування 3 соціальним оточенням пацієнта, здатність до співпраці 3 іншими фахівцями та кооперації зусиль задля забезпечення якісного медичного обслуговування пацієнта, почуття відповідальності за результати своєї діяльності перед окремим індивідом та суспільством тощо ${ }^{17}$.

У процесі професійної підготовки майбутніх фахівців iз громадського здоров'я особливу увагу необхідно приділяти й актуальному напрямку сучасної медицини - медичній екології людини, що сприяє створенню безпечних умов праці та побуту ${ }^{18}$. Адже боротьба 3 «хворобами цивілізації» в умовах сучасного світу повинна будуватися 3 урахуванням того, що антропогенний вплив буде загострюватися навіть незалежно від заходів щодо збереження природи.

У сучасних умовах забруднення навколишнього середовища актуалізуються й екологічні проблеми харчування людини. Тому необхідно відшукувати шляхи екологічної реабілітації та засоби оздоровлення людей; одним із головних заходів $\epsilon$ забезпечення їх питною водою найвищої якості. Необхідно проводити детоксикацію організму шляхом вживання природних ентеросорбентів, які ефективно виводять токсини 3 організму (сухі пшеничні висівки; пектиновітамінні драже; шроти 3 насіння; лігнін - ефективний ентеросорбент 3 деревини хвойних порід; пектин - у водоростях, фруктах, цукровому

17 Здоров'язбережувальні технології в освітньому середовищі: колективна монографія / за заг. ред. Л.М. Рибалко. Тернопіль : Осадца В. М., 2019. 400 с. С. 177.

18 Келлер А.А., Кувакин В.И. Медицинская экология / под ред. А.А. Келлера. Санкт-Петербург : Петрогардский и Ко, 1998. 256 с. С. 81. 
буряку, кошиках соняшнику, фруктовій макусі, на чому наголошують дослідники Ю. Бойчук, Е. Солошенко, В. Смоляр, О. Циганенко ${ }^{19}$.

Саме тому необхідно звертати належну увагу й на дієтологію й навчати цьому студентів спеціальності «Громадське здоров'я», адже попередити захворювання - завжди надійніше для здоров'я; простіше, ефективніше й економічно вигідніше, аніж потім його лікувати, до того ж отримуючи певні небажані побічні дії від тих чи інших препаратів.

Важливим моментом у контексті професійної підготовки майбутніх фахівців із громадського здоров'я $\epsilon$ також i формування у них компетентності щодо попередження такого негативного прояву, як нейротизм, що згубно впливає на здоров'я населення, забезпечуючи вразливість для широкого спектра різних форм психопатології, включаючи тривожні розлади, порушення настрою, хімічні залежності, соматичні симптоми та розлади прийому їжі ${ }^{20}$. Нейротизм також пов'язаний зі зниженням якості життя, в тому числі з переживанням ворожості, надмірним занепокоєнням, професійної та подружньої незадоволеністі ${ }^{21}$. Високий рівень нейротизму спричиняе низьку продуктивність праці через емоційну стурбованість, виснаження й відволікання уваги, що також необхідно враховувати в професійній підготовці майбутніх фахівців із громадського здоров'я.

Слід зауважити, що основними завданнями навчальної дисципліни «Соціальна медицина, громадське здоров'я» є: засвоєння студентами теоретичних основ біостатистики; опанування сучасних принципів доказової медицини; ознайомлення з методиками визначення й аналізу основних біостатистичних показників і критеріїв; засвоєння методичних та теоретичних основ формування статистичних сукупностей для їхнього подальшого адекватного аналізу; засвоєння методів визначення, аналізу й оцінки основних показників популяційного здоров'я за окремими критеріями та у взаємозв'язку з чинниками, що на нього впливають; засвоєння закономірностей i особливостей формування популяційного здоров'я; засвоєння принципів розробки заходів задля збереження та зміцнення здоров'я населення й окремих його контингентів; засвоєння теоретичних основ $\mathrm{i}$ правових засад системи охорони здоров'я, іiі функцій та стратегічних напрямів розвитку; засвоєння засад, напрямів, завдань системи громадського здоров'я; засвоєння основ організації медичної допомоги, принципів оцінки організації та якості надання різних видів медичної

19 Бойчук Ю.Д., Солошенко Е.М., Смоляр В.І., Циганенко О.І. Екологічні проблеми харчування людини. Київ : Око-плюс, 2002. 92 с.

${ }^{20}$ Widiger TA. In: Leary MR, Hoyle RH (eds). Handbook of individual differences in social behavior. New York: Guilford, 2009:129-46.

${ }^{21}$ Ozer DJ, Benet-Martinez V. Annu Rev Psychol, 2006. 401, 21. 
допомоги населенню в умовах реформування галузі охорони здоров'я; формування знань з питання експертизи втрати працездатності, ії видів, порядку організації та дій медичних працівників щодо конкретних ситуацій експертизи втрати працездатності; засвоєння принципів розробки управлінських рішень, спрямованих на вдосконалення діяльності закладів охорони здоров'я; опанування основ економічного аналізу діяльності медичного закладу; засвоєння принципів аналізу й оцінки фінансово-економічних показників господарської діяльності медичних закладів 3 метою раціонального використання наявних ресурсів; формування знань з питань цінової політики, стратегічного та тактичного планування економічного розвитку медичного закладу; ознайомлення з розробкою бізнес-плану підприємницької діяльності в системі охорони здоров'я.

Суттєву роль у професійній підготовці майбутніх фахівців із громадського здоров'я має відігравати виробнича практика, яка, наприклад, в межах Запорізького державного медичного університету проводиться відповідно до положення про організацію та проведення практики студентів. Виробнича практика має на меті набуття студентами професійних навичок зі спеціальності, систематизацію, закріплення й розширення знань, отриманих під час вивчення циклу професійної та практичної підготовки, розвиток професійного мислення, прищеплених умінь організаторської діяльності в умовах лікувально-профілактичного закладу. Після проходження виробничої практики складається диференційований залік, який приймається методичним керівником від навчального закладу та безпосереднім i загальним керівником від лікувально-профілактичної установи. Оцінка з практики вноситься в залікову відомість за підписом членів комісії.

Підготовка фахівців у галузі громадського здоров'я має базуватися основі медико-профілактичних факультетів, оскільки саме в їхніх межах наразі $є$ грунтовні програми переддипломної підготовки 3 громадського здоров'я.

Наприклад, у Дебреценському університеті, в сусідній Угорщині, в результаті навчання за спеціальністю «Громадське здоров'я» бакалаври та магістри не будуть власне займатися клінічною практикою, у програмах зроблено акцент на промоції здоров'я, вивченні популяційного здоров'я, факторів ризику виникнення захворювань тощо. Фахівці, які закінчили свої дослідження, будуть мати глибокі знання в галузі епідеміології, зміцнення здоров'я, управління охороною здоров'я, а також політики в галузі охорони здоров'я Програма навчання включає основні предмети (біостатистика і епідеміологія, політика в галузі охорони здоров'я та системи охорони здоров'я, пропаганда здорового способу життя); професійні предмети (гігієна 
довкілля та епідеміологія, проблеми громадської охорони здоров'я та знедолені), спеціалізовані професійні предмети (гігієна харчування, епідеміологія інфекційних хвороб, епідеміологія неінфекційних захворювань, епідеміологія захворювань із важливим значенням для громадського здоров'я, генетична епідеміологія, планування i управління проектом). Передбачено також факультативні предмети та виконання дипломної роботи ${ }^{22}$.

\section{ВИСНОВКИ}

Від розвитку системи охорони здоров'я, від якості професійної підготовки майбутніх фахівців із громадського здоров'я в закладах вищої медичної освіти сьогодні безпосередньо залежить здоров'я нації та іii майбутнє. Тому наразі загострюється проблема вивчення позитивного зарубіжного досвіду із цієї проблеми, адаптації його до національних особливостей, суспільно-політичних та соціальноекономічних умов сучасної України на їі шляху до євроінтеграції.

В Україні необхідно зосередити всі професійні, інтелектуальні, фінансові ресурси, і спираючись на основні положення Європейського плану дій зі зміцнення потенціалу служб громадського здоров'я, розробити дієві механізми та напрямки діяльності щодо розвитку цієї сфери, а саме: підготовка власне фахівців із громадського здоров'я (бакалавр, магістр, доктор філософії, безперервний професійний розвиток); навчання лікарів різних спеціальностей, для яких знання 3 галузі громадського здоров'я потрібні в щоденній фаховій діяльності; спеціальна підготовка психологів, юристів, соціологів, фахівців 3 фінансового забезпечення - для роботи в системі громадського здоров'я.

Слід зауважити, що в країнах Свропи впроваджено триступеневу освіту за фахом «громадське здоров'я»: бакалаври, магістри та доктори філософії в галузі медицини. Такий досвід міг би стати дуже актуальним і корисним для української системи охорони здоров'я. Необхідно адаптувати до національної специфіки медичної освіти навчальні програми, розширити й доповнити їх, ввести нові дисципліни, спрямовані на різнобічну професійну підготовку майбутніх фахівців із громадського здоров'я. Окрім того, необхідно повністю переорієнтувати медико-профілактичні факультети у факультети громадського здоров'я, створити вузькопрофільні випускні

22 Грузєва Т.С., Гречишкіна Н.В., Литвинова Л.О. Громадське здоров'я (Public Health) як нова спеціальність: сучасні підходи до викладання (на прикладі Дебреценського університету, Угорщина). Україна. Здоров’я нації. 2017. № 1(42). C. $166-171$, c. 168. 
кафедри: політики охорони здоров'я; біоетики; громадського здоров'я; медицини праці та професійного здоров'я. Необхідно системно підійти до вирішення цього питання й науково-методичного забезпечення ефективної, якісної професійної підготовки медичних та управлінських кадрів для сфери громадського здоров'я, що грунтується на позитивних i прийнятних для України прикладах зарубіжного досвіду, зокрема розвитку громадського здоров'я в країнах Європи, США, Канади, Великобританії тощо. Необхідно внести певні зміни в чинні університетські програми медико-профілактичних факультетів, зокрема переорієнтувати дисципліну «Інфекційна епідеміологія» на дисципліну «Епідеміологія неінфекційних та інфекційних захворювань».

\section{АНОТАЦІЯ}

У статті порушено проблему професійної підготовки майбутніх фахівців із громадського здоров'я в Україні. Розкрито сутність понять «система охорони здоров'я», «громадське здоров'я». Висвітлено окремі аспекти зарубіжного досвіду й окреслено вітчизняні перспективи щодо розвитку сфери громадського здоров'я та підготовки кваліфікованих кадрів для неї. Акцентовано на вивченні позитивного зарубіжного досвіду щодо розвитку громадського здоров'я в Угорщині, США, Канади, Великобританії, Казахстані тощо. Визначено особливості формування у майбутніх фахівців із громадського здоров'я готовності до здоров'язбережувальної діяльності з позиції викладачів-клініцистів. Відображено педагогічні погляди щодо шляхів і напрямів професійної підготовки майбутніх фахівців із громадського здоров'я. Підкреслено необхідність системного підходу до науково-методичного забезпечення ефективної, якісної професійної підготовки медичних та управлінських кадрів для сфери громадського здоров'я. Запропоновано внести грунтовні зміни в чинні університетські програми медикопрофілактичних факультетів і вдосконалити програми переддипломної та фахової підготовки з громадського здоров'я в українських закладах вищої медичної освіти.

\section{ЛІТЕРАТУРА}

1. Закон України «Основи законодавства України про охорону здоров'я». URL: http://bs-staff.com.ua/pb_ot/1085_165_37.html.

2. Гончаренко М.С. Духовность, здоровье, образование : учеб. пособ. Харьков : «БУРУН КНИГА», Киев : КНТ, 2011. 176 с.

3. Грибан В.Г. Валеологія : навч. посібник для студентів ВНЗ. Київ : Центр навчальної літератури, 2008. 256 с. 
4. Загальна теорія здоров'я та здоров'язбереження : колективна монографія / за заг. ред. проф. Ю.Д. Бойчука. Харків : Вид. Рожко С. Г., 2017. $488 \mathrm{c}$.

5. Устав Всемирной Организации Здравоохранения. URL: http://apps.who.int/gb/bd/PDF/bd47/RU/constitution.ru.pdf.

6. Апанасенко Г.Л. Попова Л.А. Медицинская валеология. Ростовна-Дону : Феникс, 2000. 243 с.

7. Грузєва Т.С., Курило Т.М. Особливості підготовки фахівців громадського здоров'я в Республіці Казахстан. Україна. Здоров'я нащиï. 2017. № 1(42). С. 162-165.

8. Вишньовська К. Проблеми реформування системи охорони здоров’я в Україні. Світ фінансів. 2008. № 3(16). С. 78-86.

9. Загальна теорія здоров'я та здоров'язбереження : колективна монографія / за заг. ред. проф. Ю.Д. Бойчука. Харків : Вид. Рожко С.Г., 2017. $488 \mathrm{c}$.

10. Романова С.М. Коучинг як нова технологія в професійній освіті. URL: http://ecobio.nau.edu.ua/index.php/VisnikPP/article/viewFile/ $2145 / 2136$.

11. Павленко Л.А. Впровадження інноваційних освітніх технологій як основа оновлення системи науково-методичної роботи закладу освіти. URL: http://virtkafedra.ucoz.ua/el_gurnal/pages/vyp7/konf2/ Pavlenko_LA.pdf.

12. Бойченко Т.Є. Освітні програми формування здорового способу життя молоді. Київ : Укр. ін-т соціальних досліджень, 2005. $120 \mathrm{c}$.

13. Оржеховська В.М. Духовність і здоров'я. Черкаси : ПП Чабаненко Ю. А., 2007. 216 с.

14. Лищук В.Д. Научные основы здоровья. Вестник АМН. 1994. № 4. C. 55-59.

15. Митяева А.М. Здоровьесберегающие педагогические технологии : учеб. пособ. Москва : Изд. центр «Академия», 2008. 192 с.

16. Піскун І.П., Кіт Ю.В. Безпека життєдіяльності (психофізіологічні аспекти) : навч. посіб. Львів : «Афіша», 2000. 239 с.

17. Здоров'язбережувальні технології в освітньому середовищі: колективна монографія / за заг. ред. Л.М. Рибалко. Тернопіль, 2019. $400 \mathrm{c}$.

18. Келлер А.А., Кувакин В.И. Медицинская экология / под ред. А.А. Келлера. Санкт-Петербург : Петрогардский и Ко, 1998. 256 с.

19. Бойчук Ю.Д., Солошенко Е.М., Смоляр В.І., Циганенко О.I. Екологічні проблеми харчування людини. Київ : Око-плюс, 2002. 92 с.

20. Widiger TA. In: Leary MR, Hoyle RH (eds). Handbook of individual differences in social behavior. New York: Guilford, 2009. 129. 
21. Ozer DJ, Benet-Martinez V. Annu Rev Psychol, 2006. 57. 401.

22. Грузсва Т.С., Гречишкіна Н.В., Литвинова Л.О. Громадське здоров'я (Public Health) як нова спеціальність: сучасні підходи до викладання (на прикладі Дебреценського університету, Угорщина). Україна. Здоров’я наиіï. 2017. № 1(42). С. 166-171.

\section{Information about the authors:}

Diachenko M. D.,

Doctor at Pedagogical Sciences, Professor at the Department of Translation Theory and Practice Classical Private University 70-B, Zhukovsky str., Zaporizhzhia, Ukraine

Zakusilova T. A.,

Ph.D. in Pedagogic Sciences, Lecturer at the Department of the Health Care, Social Medicine and Medical Expertise Zaporozhye State Medical University 26, Mayakovsky Prospect, Zaporizhzhia, Ukraine 